Check for updates

Cite this: RSC Adv., 2017, 7, 31042

Received 22nd March 2017

Accepted 31st May 2017

DOI: $10.1039 / \mathrm{c} 7 \mathrm{ra03359a}$

rsc.li/rsc-advances

\title{
Well-crystallized borax prepared from boron- bearing tailings by sodium roasting and pressure leaching
}

\author{
Wei Xie, (D) *a Chengxi Zou, ${ }^{\text {a }}$ Zhenyu Tang, ${ }^{\text {a }}$ Hanguang Fu, ${ }^{\mathrm{b}}$ Xukun Zhu, ${ }^{\mathrm{a}}$ Jiacai Kuang ${ }^{\mathrm{a}}$ \\ and Yingjun Deng ${ }^{a}$
}

\begin{abstract}
We report a low-cost and effective technique for preparing borax from boron-bearing tailings, which is at a low grade of $9.98 \% \mathrm{~B}_{2} \mathrm{O}_{3}$. Well-crystallized borax is achieved by the removal of impurity, evaporation and concentration through the efficient method of sodium roasting and pressure leaching. The morphology, composition and structure of borax are investigated in this study. The result of scanning electron microscopy shows that the crystals obtained are cube-shaped with smooth surface and of good growth. The crystals are proven to be $\mathrm{Na}_{2} \mathrm{~B}_{4} \mathrm{O}_{7} \cdot 10 \mathrm{H}_{2} \mathrm{O}$ by EDS, XPS, XRD and ICP-AES. Moreover, the recovery rate of boron can reach $63.49 \%$. This cost-effective strategy of preparing borax from boron-bearing tailings provides a guideline for the development of the boron industry and has a great potential for the commercialization of borax production.
\end{abstract}

\section{Introduction}

Borax ${ }^{1-3}$ borax hydrates, ${ }^{4}$ boric acid, ${ }^{5,6}$ borate, ${ }^{7}$ sodium metaborate,$^{8-10}$ boron-based propellant and whisker composite $^{11,12}$ are commercially important boron compounds. Borax, or sodium tetraborate, with a molecular formula of $\mathrm{Na}_{2} \mathrm{~B}_{4} \mathrm{O}_{7} \cdot 10 \mathrm{H}_{2} \mathrm{O}$, is a very important boron-bearing mineral and boron compound. Borax usually appears as a type of colorless translucent crystal or white crystalline powder that is odorless, tastes salty and loses all the crystal water at $380{ }^{\circ} \mathrm{C}$. It is soluble in water and glycerol and slightly soluble in alcohol, and its aqueous solution is weakly alkaline. Borax weathers slowly in air, and changes into a colorless glassy material when melted. Borax has a bactericidal effect, and is orally harmful to humans. As one of the main boron compounds, borax is widely used in over 100 industries for the production of borosilicate glass, enamels, leather, detergents, cosmetics, textile-grade fibers, fire retardants, artificial fertilizers, insecticides, disinfectants and drugs due to its special chemical and physical properties. ${ }^{13,14}$ It is mainly used in glass and enamel industries. When applied in glass, it enhances the transmittance of ultraviolet light and improves the transparency of glass and heat resistance. When used in enamel products, the enamel shines better and does not shed easily. ${ }^{15,16}$ In addition, it is also used as an alternative energy source, and new application fields of boron will continue to be expanded.

${ }^{a}$ Hunan Province Key Laboratory of Safety and Reliability Technology for Engineering Vehicle, Changsha University of Science and Technology, Changsha 410114, China ${ }^{b}$ College of Materials Science and Engineering, Beijing University of Technology, Beijing 100124, China
As a substituted material of szaibelyite, a boron-concentrate ore selected from paigeite by a magnetic-gravity concentrator is used to prepare borax. ${ }^{17}$ However, this type of raw material is gradually eliminated because it is difficult to be processed with its complex structure and low grade. ${ }^{18}$ Furthermore, with an increase in boron consumption worldwide, it may get exhausted after several decades, and thus, will be unable to meet the needs of the developing boron industry. Therefore, development and utilization of other boron resources become a task of top priority. It has previously been reported that the leaching of boron has determined the degree of difficulty in the preparation of borax and boric acid. Therefore, improving the leaching of boron during the use of boron ore presents as one of the key scientific problems. Finding a material with reserves large enough to sustain continuous production of borax remains a major challenge. At present, the world boron consumption is greater than 1.5 million tons per year in terms of boron oxide, and it is increasing gradually. Boron minerals are distributed in only a few areas around the world. ${ }^{19,20}$ Considering the comprehensive utilization and sustainable development of boron resource, choosing a more valuable material for preparing borax is a critical matter for the moment. China ranks after Turkey, the USA and Russia in boron reserves since China has abundant boron resources, particularly boron-bearing tailings due to the extraction of iron from paigeite. ${ }^{21}$ For this reason, it is necessary to utilize the boron-bearing tailings to produce borax efficiently in order to avoid environmental problems as well as economical loss.

A number of research projects have been carried out to date, and numerous methods have also been proposed for the preparation of borax from boron deposits, such as the sulfuric acid 
method, ${ }^{22}$ alkaline hydrolysis method, ${ }^{23}$ carbonate alkaline method, ${ }^{24,25}$ sodium roasting and atmospheric leaching method, ${ }^{26}$ molten sodium and atmospheric leaching method as well as sodium roasting and pressure leaching method. ${ }^{27,28}$ Among these techniques for preparing borax, the sulfuric acid method was applied several years ago. It is easy to get boric acid and borax, but the cost is high and the scope of application is narrow owing to the use of strong sulfuric acid, which leads to serious equipment corrosion and is harmful to the environment as well as human health. The alkaline hydrolysis method has a high alkali solution rate. However, long process flow and large energy consumption are its most conspicuous defects. The carbonate alkaline method can obtain borax of excellent quality with high efficiency, but its facility requirements are high and the experimental condition is difficult to control because of the production of carbon dioxide gas. Obtain borax using the sodium roasting and atmospheric leaching method is a timeconsuming process, and the processing technology is not in conformity with the principle of efficiency. The molten sodium and atmospheric leaching method demands a high temperature of $1450{ }^{\circ} \mathrm{C}$, and thus the energy consumption will be the biggest problem. Comparing with the above processes, sodium roasting technology is a method that adds a sodium agent to the raw mineral materials. In this method, decomposition of the sodium agent results in $\mathrm{Na}_{2} \mathrm{O}$, which is highly active and often combines with other elements to produce soluble sodium salt to destroy the mineral structure and facilitate the leaching of the next element under a certain temperature and atmospheric condition. ${ }^{29,30}$ Therefore, we decided to prepare borax by the sodium roasting and pressure leaching method, which is the most ideal one with shorter reaction process, lower energy consumption and less environmental pollution. Furthermore, it has a high recovery rate of boron.

Based on the theory of sodium roasting, the sodium roasting and pressure leaching method is used to prepare borax from boron-bearing tailings. Our technique costs less and does not sacrifice the high recovery rate. Moreover, it effectively compensates for the disadvantages of other methods. In this study, the morphology, structure and composition of the borax crystal are also discussed. In addition, the reaction mechanism, preliminarily analyzed in this study, provides a scientific basis and reference to the preparation of borax from boron-bearing tailings with low grade.

\section{Experimental}

\subsection{Materials}

Boron-bearing tailings (Kuandian ores) were exploited in Liaoning province in China. Its chemical compositions are presented in Table 1 . The other chemicals used in the

Table 1 Chemical compositions of Kuandian ores

\begin{tabular}{lcccccccc} 
Index & $\mathrm{B}_{2} \mathrm{O}_{3}$ & $\mathrm{Na}_{2} \mathrm{O}$ & $\mathrm{Al}_{2} \mathrm{O}_{3}$ & $\mathrm{CaO}$ & $\mathrm{MgO}$ & $\mathrm{SiO}_{2}$ & $\mathrm{Fe}_{2} \mathrm{O}_{3}$ & $\mathrm{~K}_{2} \mathrm{O}$ \\
\hline Content (wt\%) & 9.98 & 0.04 & 1.36 & 2.28 & 32.43 & 28.41 & 4.88 & 0.03
\end{tabular}

experiments, including $\mathrm{Na}_{2} \mathrm{CO}_{3}, \mathrm{HCl}$ and $\mathrm{NaOH}$, were of analytical grade and supplied by Sinopharm Chemical Reagent Company. Deionized water was used during the experiments.

\subsection{Experimental procedure}

Based on the content of $\mathrm{B}_{2} \mathrm{O}_{3}$ in $15 \mathrm{~g}$ Kuandian ores and the stoichiometric ratio, a theoretical mass of $\mathrm{Na}_{2} \mathrm{CO}_{3}$ was calculated (1.13 g). To improve homogeneity, the ores were pulverized to 200 mesh, and then the $15 \mathrm{~g}$ ores and $5.65 \mathrm{~g} \mathrm{Na}_{2} \mathrm{CO}_{3}$ (five times as much as the theoretical mass) were mixed up. The mixture was added to a corundum crucible and put in a muffle furnace until the temperature of the muffle furnace reached a preset value $\left(700-950{ }^{\circ} \mathrm{C}\right)$ and remained constant. After 2 hours of reaction, the mixture was removed and pulverized to 200 mesh. According to the liquid-to-solid ratio of $5: 1,8 \mathrm{~g}$ mixture that was pulverized and $40 \mathrm{~mL}$ deionized water were put into an autoclave, the temperature of which was controlled by a programmable temperature controller at $150{ }^{\circ} \mathrm{C}$. Then, the reactor was heated with continuous stirring (namely, the process of leaching), which lasted for 6 hours. After the leaching process was over, the autoclave cooled automatically within 5-6 hours. The reactant of the slurry sample was taken out, followed by filtration to obtain a filtrate. In order to crystallize the high-purity borax, the $\mathrm{pH}$ value of the filtrate was adjusted to 9, which could precipitate the silicate, and then filtered again to get another filtrate. Well-crystallized borax was obtained from the second filtrate after impurity removal, evaporation and concentration. Then, the boron recovery $x(\%)$ was examined, which is defined below

$$
x(\%)=\frac{\text { amount of } \mathrm{B}_{2} \mathrm{O}_{3} \text { in the crystallized borax }}{\text { amount of } \mathrm{B}_{2} \mathrm{O}_{3} \text { in the leaching sample }} \times 100
$$

\subsection{Characterization}

The chemical compositions of boron-bearing tailings were analyzed using an X-ray fluorescence spectrometer (PW2440X). The morphologies of the crystals were identified by scanning electron microscopy (SEM, TESCAN MIRA3 LMU type, Japan). The TESCAN MIRA3 LMU-type scanning electron microscope was equipped with the Oxford X-Max20 Energy spectrum system. The X-ray diffraction (XRD) patterns of the crystals were recorded on the $\mathrm{D} / \mathrm{max} 2550 \mathrm{VB}+\mathrm{X}$-ray diffractometer using $\mathrm{Cu} \mathrm{K} \alpha$ radiation $(k=0.154178 \mathrm{~nm})$ with $40 \mathrm{kV}$ scanning voltage and $40 \mathrm{~mA}$ scanning current, and its scan range was from $5^{\circ}$ to $70^{\circ}$. The elemental compositions of boron-bearing tailings and borax were determined using an inductively coupled plasma atomic emission spectrometer (ICP-AES, ICAP-7600). X-ray photoelectron spectra (XPS) were recorded on a K-Alpha 1063 photoelectron spectrometer using $\mathrm{Al} \mathrm{K \alpha}(h \nu$ $1486.6 \mathrm{eV}$ ) X-ray as the excitation source. Fourier transform infrared spectroscopy-attenuated total reflectance (FTIR-ATR) spectra were recorded on a Fourier transform infrared spectrometer (WQF-510A). 


\section{Results and discussion}

Unlike other reported methods, we chose the boron-bearing tailing namely Kuandian ores, whose grade is only $9.98 \%$, as the raw material. Owing to its abundant reserves and the gradual shortage of the boron-concentrate ore, it was of great significance to adopt Kuandian ores as the raw material in the borax preparation industry. TG-DTA analysis was carried out to investigate the thermal behaviors of Kuandian ores. As shown in Fig. 1(a), the TG curve declined slowly at the initial temperature $\left(0-520^{\circ} \mathrm{C}\right)$. Moreover, owing to the removal of surface-absorbed water, the sample lost a small amount of weight. When the temperature reached $588.8^{\circ} \mathrm{C}$, the DTA curve presented an evident exothermic peak, the main cause of which was that a large amount of $\mathrm{Fe}^{2+}$ in the sample was oxidized to $\mathrm{Fe}^{3+}$. However, in this process, compared with its weight gain, the weight loss of the sample was more significant. For this reason, there was no peak in the TG curve at that temperature. Between $623.8{ }^{\circ} \mathrm{C}$ and $703.5{ }^{\circ} \mathrm{C}$, a continuous and deep endothermal trough occurred in the DTA curve. Moreover, the TG curve declined sharply at the same time, and the weight loss rate reached as high as about $4.5 \%$ in this region, the most convincing reason of which was that szaibelyite $\left(\mathrm{Mg}_{2}(\mathrm{OH})\left[\mathrm{B}_{2} \mathrm{O}_{4}(\mathrm{OH})\right]\right)$ and antigorite $\left(\mathrm{Mg}_{6}\left[\mathrm{Si}_{4} \mathrm{O}_{10}\right](\mathrm{OH})_{8}\right)$ of the ores were dehydrated into suanite $\left(\mathrm{Mg}_{2} \mathrm{~B}_{2} \mathrm{O}_{5}\right)$ and forsterite $\left(\mathrm{Mg}_{2} \mathrm{SiO}_{4}\right)$, respectively. ${ }^{31,32}$ The temperature was increasing continuously and, when it reached $808.7^{\circ} \mathrm{C}$, there was a shallow and narrow exothermic peak on the DTA curve, and the corresponding TG curve increased slightly. This was probably due to an exothermic effect, which was caused by the transformation of $\mathrm{Fe}^{2+}$ into $\mathrm{Fe}^{3+}$. Fig. 1(b) shows the TG-DTA curve of Kuandian ores $/ \mathrm{Na}_{2} \mathrm{CO}_{3}$. The exothermic peak occurred when the temperature reached about $588.8^{\circ} \mathrm{C}$. It is generally similar to the curve of Kuandian ores. However, there was a greater weight loss than that shown in Fig. 1(a). When the temperature reached $1000{ }^{\circ} \mathrm{C}$, the weight loss rate was more than $40 \%$. This may be due to the reaction between $\mathrm{Na}_{2} \mathrm{CO}_{3}$ and $\mathrm{Mg}_{2} \mathrm{~B}_{2} \mathrm{O}_{5}$ (the dehydrated product of szaibelyite and antigorite). Therefore, adding $\mathrm{Na}_{2} \mathrm{CO}_{3}$ to the ores could increase the sodium reaction and facilitate the transformation from boron into well-crystallized borax.

According to the analysis results of TG-DTA, we calcined the mixtures of the tailings and $\mathrm{Na}_{2} \mathrm{CO}_{3}$ at different temperatures,
Table 2 The boron recovery of samples roasted at different calcination temperatures

\begin{tabular}{lcccccc}
\hline Temperature $\left({ }^{\circ} \mathrm{C}\right)$ & 700 & 750 & 800 & 850 & 900 & 950 \\
\hline Boron recovery (\%) & 28.09 & 34.14 & 40.76 & 45.53 & 60.51 & 63.49
\end{tabular}

varying from $700{ }^{\circ} \mathrm{C}$ to $950{ }^{\circ} \mathrm{C}$. When the temperature reached $700{ }^{\circ} \mathrm{C}$, suanite $\left(\mathrm{Mg}_{2} \mathrm{~B}_{2} \mathrm{O}_{5}\right)$ began to appear. It was an indispensable ingredient for preparing borax. The boron recovery observed under different temperatures is shown in Table 2. A conclusion was drawn that boron recovery would increase with the increase in temperature. However, as the rising rate gradually became slower, and taking into account the energy consumption, the experiment was not conducted at a higher temperature. Therefore, we considered the experimental condition, $950{ }^{\circ} \mathrm{C}$, in the study as a relatively superior experimental condition, and subsequent detections and analyses were also performed on products that were obtained under this condition. Fig. 2 illustrates the morphology of the sample prepared by the sodium roasting and pressure leaching method. The SEM image was enlarged 2000 fold. It can be seen from Fig. 2(a) that the Kuandian ores were in a powdered form with a small amount of bulk. As shown in Fig. 2(b), the samples were aggregated and showed a porous surface structure, which may be due to the release of carbon dioxide during the reaction. In addition, the porous surface structure led to a faster reaction between ores and molten $\mathrm{Na}_{2} \mathrm{CO}_{3}$ and formed a fluffy cluster; thus, it was easier to recover boron under this condition. The morphology of crystals is shown in Fig. 2(c). The image shows that the borax product was massive with a smooth surface and showed good crystal growth. To prove the element composition and ratio, the purity of the crystals was analyzed by elemental analysis, SEM with energy-dispersive X-ray spectrometry (EDS), and the results are given in Fig. 2(d). Elemental analysis showed that there were three elements in the crystals, including $\mathrm{Na}$, B and $\mathrm{O}$ elements.

The XRD patterns of Kuandian ores, sodium roasting samples and the crystals are shown in Fig. 3. In Fig. 3(a), we can see all the phases of Kuandian ores. The major phases were antigorite $\left(\mathrm{Mg}_{6}\left[\mathrm{Si}_{4} \mathrm{O}_{10}\right](\mathrm{OH})_{8}\right)$, talcum $\left(\mathrm{Mg}_{3}\left[\mathrm{Si}_{4} \mathrm{O}_{10}\right](\mathrm{OH})_{2}\right)$,


Fig. 1 TG-DTA curve of (a) Kuandian ores and (b) Kuandian ores $/ \mathrm{Na}_{2} \mathrm{CO}_{3}$. 

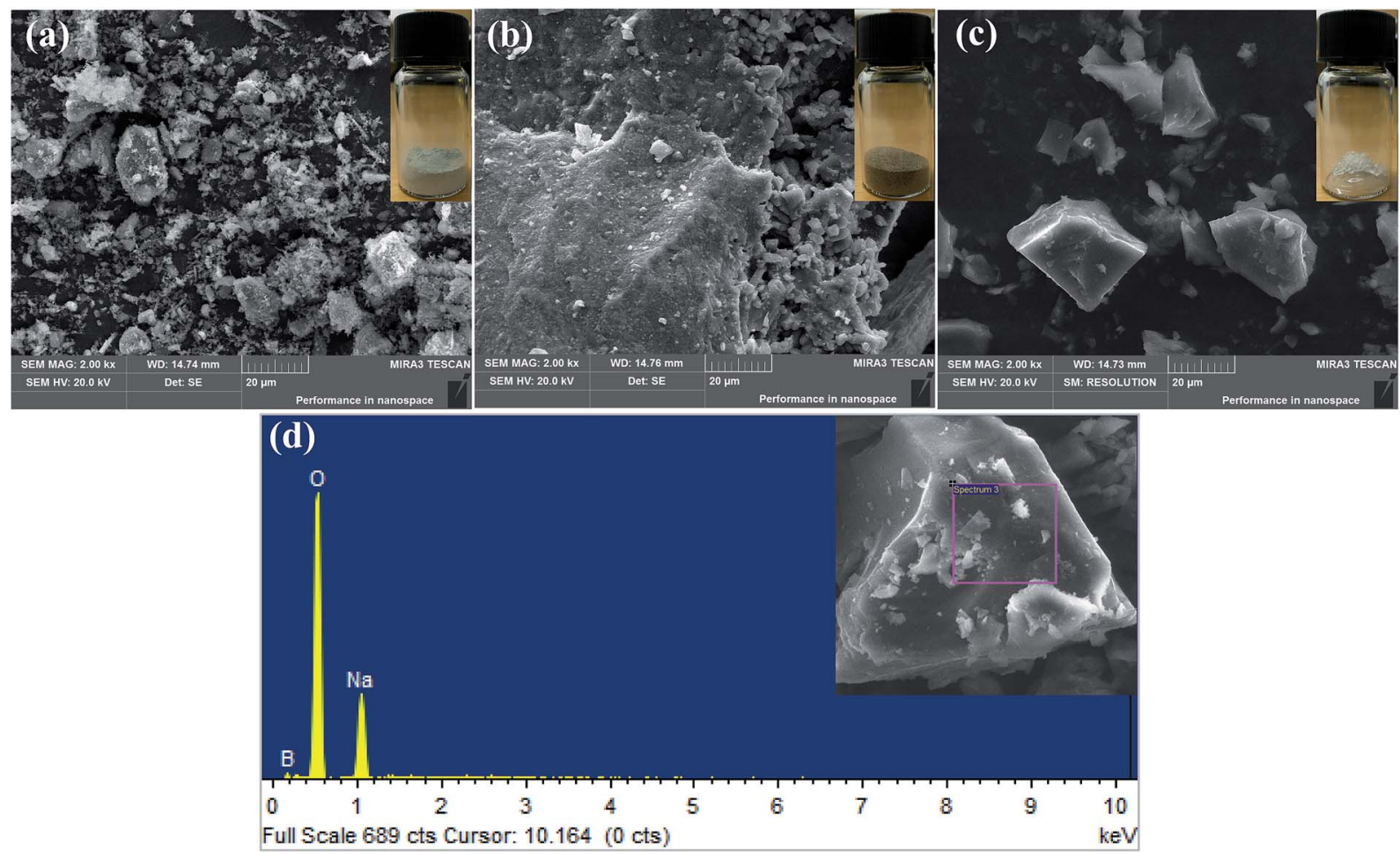

Fig. 2 SEM patterns of (a) Kuandian ores, (b) samples roasted at $950{ }^{\circ} \mathrm{C}$, (c) crystals and (d) EDS pattern of crystals.

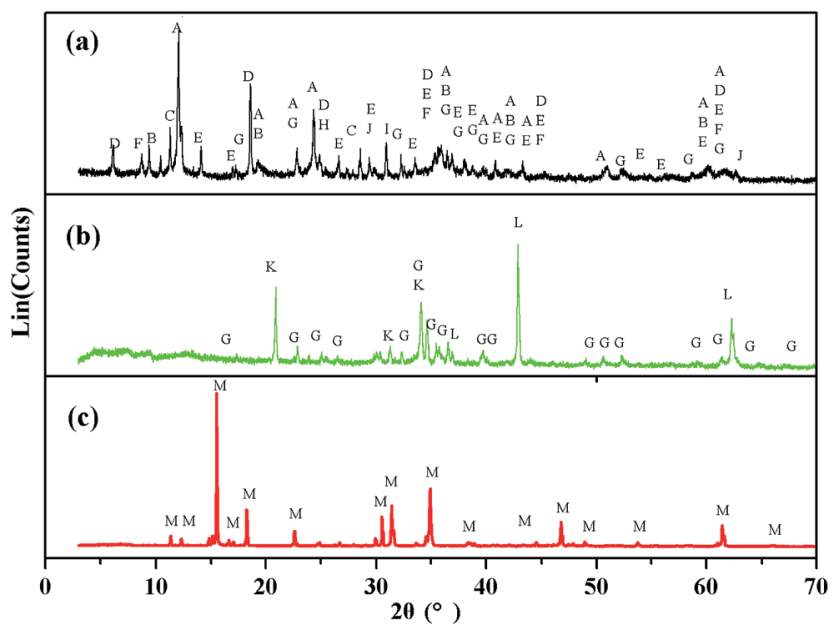

Fig. 3 XRD pattern of (a) Kuandian ores, (b) samples roasted at $950^{\circ} \mathrm{C}$ and (c) the crystals. (A) $\mathrm{Mg}_{6}\left[\mathrm{Si}_{4} \mathrm{O}_{10}\right](\mathrm{OH})_{8} ;(\mathrm{B}) \mathrm{Mg}_{3}\left[\mathrm{Si}_{4} \mathrm{O}_{10}\right](\mathrm{OH})_{2} ;(\mathrm{C})$ $\mathrm{Ca}_{2} \mathrm{Mg}_{5} \mathrm{Si}_{8} \mathrm{O}_{22}(\mathrm{OH})_{2} ; \quad$ (D) $\mathrm{Mg}_{3}\left[\mathrm{Si}_{4} \mathrm{O}_{10}\right](\mathrm{OH})_{2} \mathrm{Mg}_{3}(\mathrm{OH})_{6} ; \quad$ (E) $\mathrm{Mg}_{2}(\mathrm{OH})$ $\left[\mathrm{B}_{2} \mathrm{O}_{4}(\mathrm{OH})\right] ; \quad$ (F) $\mathrm{KAl}_{2}\left(\mathrm{AlSi}_{3} \mathrm{O}_{10}\right)(\mathrm{OH})_{2} ;$ (G) $\mathrm{Mg}_{2} \mathrm{SiO}_{4} ; \quad$ (H) $\mathrm{SiO}_{2} ;$ (I) $\mathrm{CaMg}\left(\mathrm{CO}_{3}\right)_{2} ;$ (J) $\mathrm{Fe}_{3} \mathrm{O}_{4} ;(\mathrm{K}) \mathrm{Na}_{2} \mathrm{~B}_{4} \mathrm{O}_{7} ;(\mathrm{L}) \mathrm{MgO}$; (M) $\mathrm{Na}_{2} \mathrm{~B}_{4} \mathrm{O}_{7} \cdot 10 \mathrm{H}_{2} \mathrm{O}$.

tremolite $\left(\mathrm{Ca}_{2} \mathrm{Mg}_{5} \mathrm{Si}_{8} \mathrm{O}_{22}(\mathrm{OH})_{2}\right)$, chlorite $\left(\mathrm{Mg}_{3}\left[\mathrm{Si}_{4} \mathrm{O}_{10}\right](\mathrm{OH})_{2}-\right.$ $\left.\mathrm{Mg}_{3}(\mathrm{OH})_{6}\right)$, szaibelyite $\left(\mathrm{Mg}_{2}(\mathrm{OH})\left[\mathrm{B}_{2} \mathrm{O}_{4}(\mathrm{OH})\right]\right)$, muscovite $\left(\mathrm{KAl}_{2}(-\right.$ $\left.\left.\mathrm{AlSi}_{3} \mathrm{O}_{10}\right)(\mathrm{OH})_{2}\right)$, forsterite $\left(\mathrm{Mg}_{2} \mathrm{SiO}_{4}\right)$, quartz $\left(\mathrm{SiO}_{2}\right)$, dolomite $\left(\mathrm{CaMg}\left(\mathrm{CO}_{3}\right)_{2}\right)$, magnetite $\left(\mathrm{Fe}_{3} \mathrm{O}_{4}\right)$ and so on. With the gradually increase in reaction time, szaibelyite $\left(\mathrm{Mg}_{2}(\mathrm{OH})\left[\mathrm{B}_{2} \mathrm{O}_{4}(\mathrm{OH})\right]\right)$ and antigorite $\left(\mathrm{Mg}_{6}\left[\mathrm{Si}_{4} \mathrm{O}_{10}\right](\mathrm{OH})_{8}\right)$ in the Kuandian ores were dehydrated into suanite $\left(\mathrm{Mg}_{2} \mathrm{~B}_{2} \mathrm{O}_{5}\right)$ and forsterite $\left(\mathrm{Mg}_{2} \mathrm{SiO}_{4}\right)$, respectively. At this point, the diffraction peak intensity of
$\mathrm{Na}_{2} \mathrm{~B}_{4} \mathrm{O}_{7}$ in the product appeared as shown in Fig. 3(b). It was the product of the chemical reaction of $\mathrm{Mg}_{2} \mathrm{~B}_{2} \mathrm{O}_{5}$ and $\mathrm{Na}_{2} \mathrm{CO}_{3}$. The amount of $\mathrm{Na}_{2} \mathrm{~B}_{4} \mathrm{O}_{7}$ gradually increased. For further determining the structure of the crystals, which were obtained by the cost-effective method under a sodium roasting temperature of $950{ }^{\circ} \mathrm{C}$, we also monitored them by X-ray diffraction. The powder XRD pattern of the crystals is presented in Fig. 3(c). We found that the pattern of the crystals was in accordance with the standard spectrogram. Thus, it was confirmed that the main crystallized product obtained was $\mathrm{Na}_{2} \mathrm{~B}_{4} \mathrm{O}_{7} \cdot 10 \mathrm{H}_{2} \mathrm{O}$.

Moreover, to observe the crystal structure composition, further studies were carried out. Boron-bearing tailings, samples roasted at $950{ }^{\circ} \mathrm{C}$ and borax crystals were analyzed by elemental analysis, ICP-AES. As shown in Table 3, the result clearly illustrated the changes in the elements and their contents in samples during the three processes in the experiment, and the reasons for the changes in the contents of some elements were also analyzed. The main metallic elements in boron-bearing tailings were $\mathrm{Al}, \mathrm{Ca}, \mathrm{Fe}, \mathrm{K}, \mathrm{Mg}, \mathrm{Na}$ and $\mathrm{Si}$ and the main nonmetallic elements were $\mathrm{B}, \mathrm{C}, \mathrm{O}$ and $\mathrm{H}$, which was similar to the result of the chemical composition analysis of the tailings in Table 1 . After roasting at $950{ }^{\circ} \mathrm{C}$, the content of $\mathrm{Na}$ in the samples increased, mainly because of the addition of $\mathrm{Na}_{2} \mathrm{CO}_{3}$ in the tailings for roasting. The contents of $\mathrm{Al}, \mathrm{K}$ and $\mathrm{Si}$ increased slightly, which might be caused by the introduction of slightly impure elements due to the experimental operation during the grinding process. The remaining elements were basically unchanged or slightly decreased. After the evaporation, concentration and cooling crystallization of the crystals, the metallic element left was only $\mathrm{Na}$ and its content was 9.99 
Table 3 Elemental compositions of (a) boron-bearing tailings, (b) samples roasted at $950{ }^{\circ} \mathrm{C}$ and (c) borax

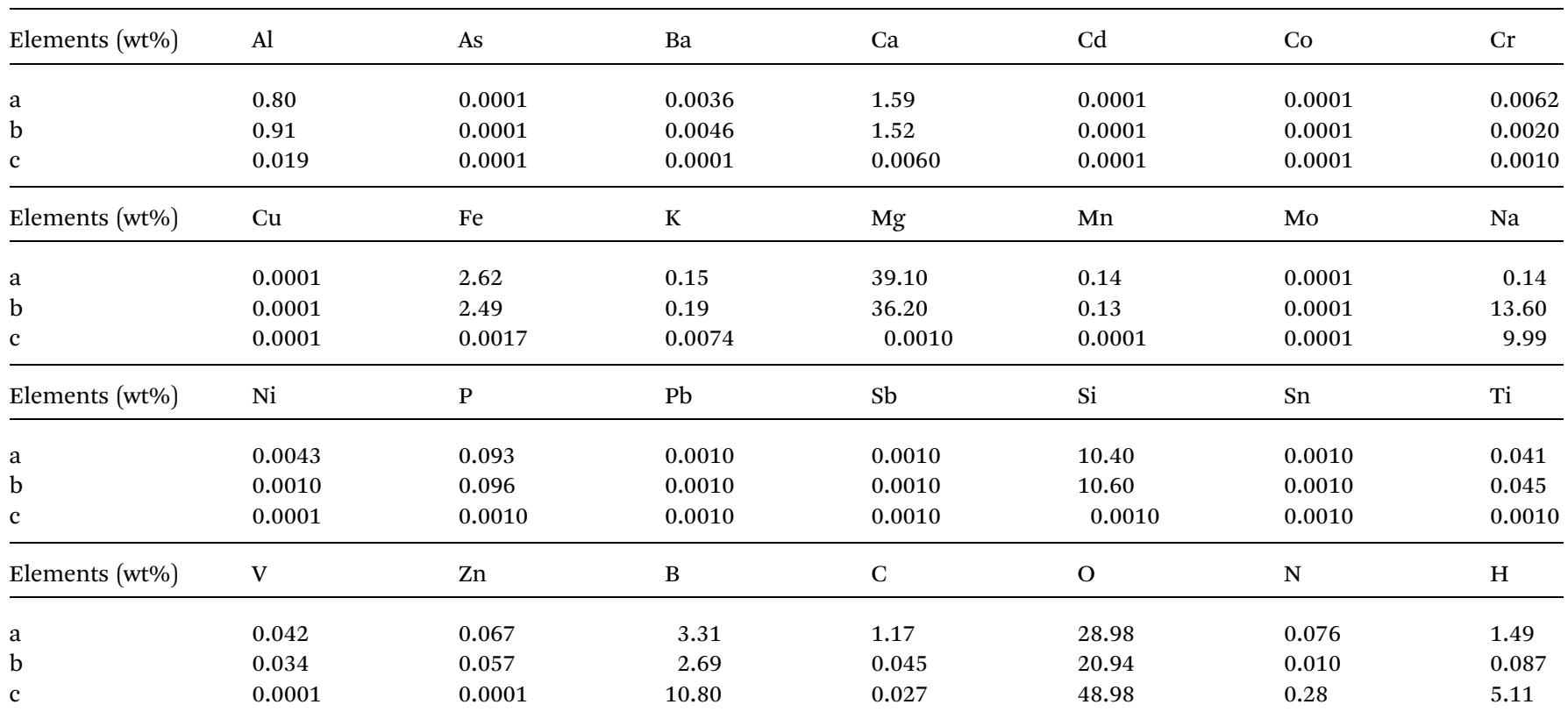

wt $\%$ with the impurities of other metallic elements all removed. The main nonmetallic elements left were $\mathrm{B}, \mathrm{O}$ and $\mathrm{H}$, and the content of B was $10.80 \mathrm{wt} \%$. Upon calculation, the ratio of the number of atoms in the crystals was as follows: $n(\mathrm{Na}): n(\mathrm{~B})=$ $1: 2$. This result was consistent with the result of the crystal chemical formula in XRD analysis, which was $\mathrm{Na}_{2} \mathrm{~B}_{4} \mathrm{O}_{7} \cdot 10 \mathrm{H}_{2} \mathrm{O}$. However, traces of $\mathrm{N}$ were included in the crystals, which might be the impure element introduced during the high-pressure leaching or crystallization process. The crystals were also confirmed by XPS. The full spectrum in Fig. 4(a) indicates the existence of $\mathrm{B}, \mathrm{Na}$ and $\mathrm{O}$ elements in the sample. Compared with the original ores, the elements $\mathrm{K}, \mathrm{Al}, \mathrm{Ca}$ and $\mathrm{Mg}$ disappeared, suggesting the removal of impurities during preparation. The impure elements were precipitated after the leaching process, and silicate precipitates were removed by adjusting the $\mathrm{pH}$ value of the filtrate to 9 in this experiment. According to the ratio of $\mathrm{Na} / \mathrm{B}$ and the peak with their binding energy of $192.01 \mathrm{eV}$, the crystal was assigned to be $\mathrm{Na}_{2} \mathrm{~B}_{4} \mathrm{O}_{7^{-}}$ $\cdot 10 \mathrm{H}_{2} \mathrm{O}$. FTIR was employed to analyze the existence of most functional groups and the changes in chemical bonds. Fig. 4(b) shows that the FTIR spectra of the borax crystal (with its peak centered at $3508 \mathrm{~cm}^{-1}$ ), which was wide and strong, were attributed to the $\mathrm{O}-\mathrm{H}$. In addition, the peaks centered at 1646 $\mathrm{cm}^{-1}, 1406 \mathrm{~cm}^{-1}$ and $1074 \mathrm{~cm}^{-1}$ were consistent with the characteristic vibration absorption peak of B-O. Furthermore, the peak observed at $831 \mathrm{~cm}^{-1}$ was attributed to the extension vibration of $\mathrm{Na}-\mathrm{O}$. It indicated that the oxygen atom had coordinated with the sodium ion. ${ }^{33}$

Based on the above results, we proposed the preparation mechanism of borax, which is shown in Fig. 5. First, during the roasting stage, the phases, szaibelyite $\left(\mathrm{Mg}_{2}(\mathrm{OH})\left[\mathrm{B}_{2} \mathrm{O}_{4}(\mathrm{OH})\right]\right)$ and antigorite $\left(\mathrm{Mg}_{6}\left[\mathrm{Si}_{4} \mathrm{O}_{10}\right](\mathrm{OH})_{8}\right)$ in the Kuandian ores, were dehydrated into suanite $\left(\mathrm{Mg}_{2} \mathrm{~B}_{2} \mathrm{O}_{5}\right)$ and forsterite $\left(\mathrm{Mg}_{2} \mathrm{SiO}_{4}\right)$ at $700{ }^{\circ} \mathrm{C}$, and the forsterite phase in the product increased gradually. This rule was in accordance with the results of differential thermal analysis. Simultaneously, $\mathrm{Na}_{2} \mathrm{~B}_{4} \mathrm{O}_{7}$ phase appeared and sodium carbonate in the system began to melt at $850{ }^{\circ} \mathrm{C}$. The sodium products were aggregated and showed a porous surface structure since the particles were encapsulated with molten $\mathrm{Na}_{2} \mathrm{CO}_{3}$. Subsequently, the increasing molten $\mathrm{Na}_{2} \mathrm{CO}_{3}$ made a transition from solid-solid reaction to solidliquid reaction, which led to the acceleration of the reaction. In
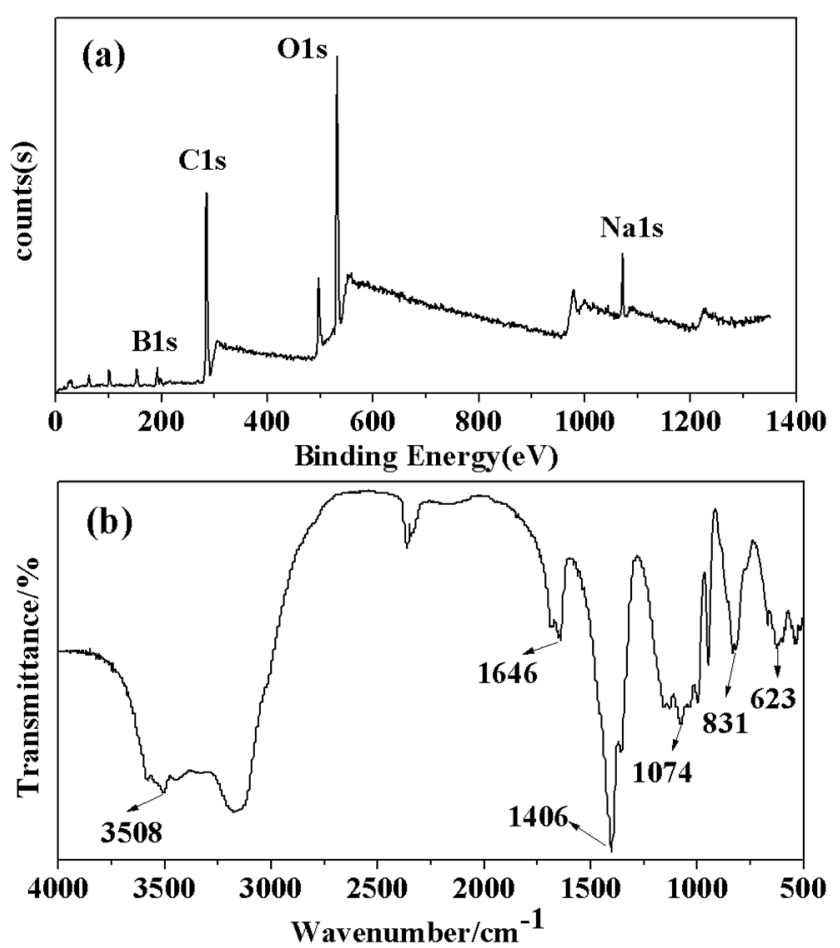

Fig. 4 (a) XPS pattern and (b) FTIR pattern of crystals. 


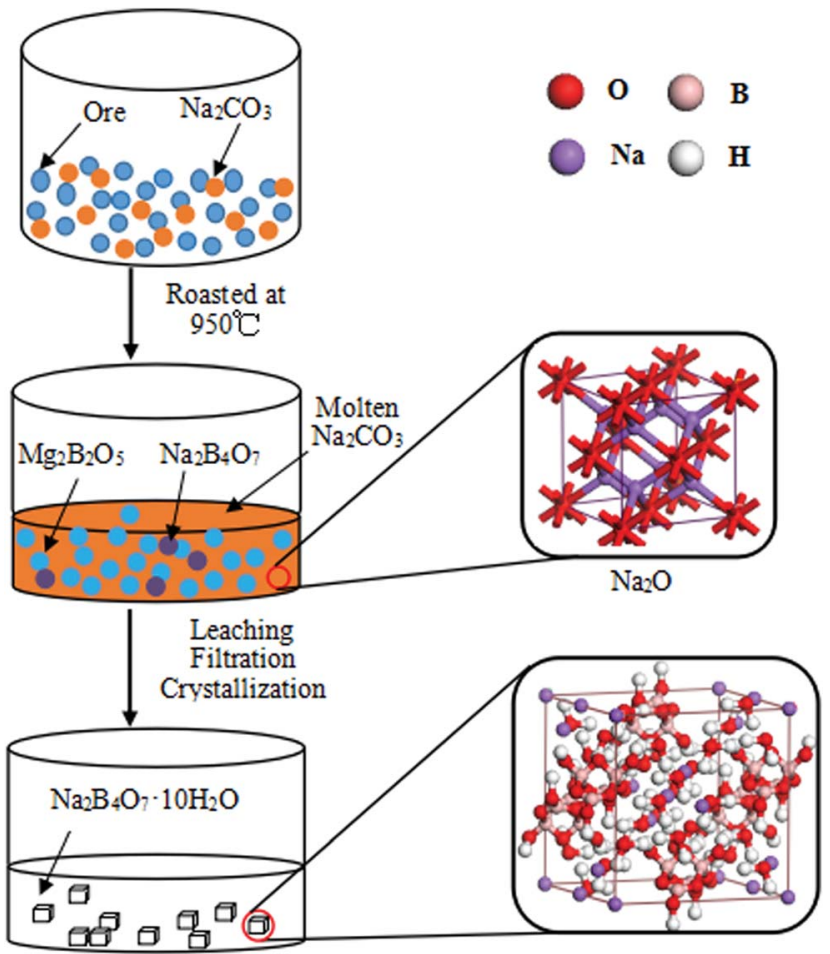

Fig. 5 Mechanism diagram of the borax prepared by sodium roasting and pressure leaching.

general, in the case of high-temperature calcination, $\mathrm{Na}_{2} \mathrm{CO}_{3}$ could be decomposed into two component parts, namely $\mathrm{Na}_{2} \mathrm{O}$ and $\mathrm{CO}_{2}$. The $\mathrm{Na}_{2} \mathrm{O}$ primitive cell is shown using the ball-andstick model in Fig. 5. Second, by further increasing the calcination temperature, the amount of $\mathrm{Na}_{2} \mathrm{~B}_{4} \mathrm{O}_{7}$ phase increased. At this point, we could learn that the diffraction peak intensity of $\mathrm{Na}_{2} \mathrm{~B}_{4} \mathrm{O}_{7}$ increased obviously. The chemical reactions were illustrated in the following three formulas. Finally, the roasted product was put into an autoclave with deionized water, and the particle size of the product was 200 meshes. After the treatments of leaching, filtration, impurity removal and crystallization, the crystal of $\mathrm{Na}_{2} \mathrm{~B}_{4} \mathrm{O}_{7} \cdot 10 \mathrm{H}_{2} \mathrm{O}$ appeared, whose atomic structure was given with a space group of $C 2 / c$. Each sodium ion was located on the crystallographic inversion symmetry center and surrounded by six oxygen donors from water in distorted octahedron geometry. The crystal structure was aggregated to a 2-D network through $\mathrm{O}-\mathrm{H}-\mathrm{O}$ hydrogen bonding involving the water molecules and tetraborate anion atoms. ${ }^{34,35}$ Such a structure could contribute to the leaching of boron. In other words, it was valuable to obtain higher boron recovery.

$$
\begin{gathered}
\mathrm{Mg}_{6} \mathrm{Si}_{4} \mathrm{O}_{10}(\mathrm{OH})_{8} \rightarrow 3 \mathrm{Mg}_{2} \mathrm{SiO}_{4}+\mathrm{SiO}_{2}+4 \mathrm{H}_{2} \mathrm{O} \\
\mathrm{Mg}_{2} \mathrm{~B}_{2} \mathrm{O}_{4}(\mathrm{OH})_{2} \rightarrow \mathrm{Mg}_{2} \mathrm{~B}_{2} \mathrm{O}_{5}+\mathrm{H}_{2} \mathrm{O} \\
2 \mathrm{Mg}_{2} \mathrm{~B}_{2} \mathrm{O}_{5}+\mathrm{Na}_{2} \mathrm{O} \rightarrow \mathrm{Na}_{2} \mathrm{~B}_{4} \mathrm{O}_{7}+4 \mathrm{MgO}
\end{gathered}
$$

\section{Conclusions}

High-quality borax, with boron-bearing tailings as raw materials, is prepared by sodium roasting and pressure leaching. The recovery rate of boron is up to $63.49 \%$ under the optimum reaction conditions of $950{ }^{\circ} \mathrm{C}$ with a low grade of $9.98 \%\left(\mathrm{~B}_{2} \mathrm{O}_{3}\right)$. It is economical to prepare borax using this technique, which can achieve a high recovery rate with low grade. Borax products obtained are cube-shaped crystals with smooth surface and show good crystal growth, and the products are proven to be $\mathrm{Na}_{2} \mathrm{~B}_{4} \mathrm{O}_{7} \cdot 10 \mathrm{H}_{2} \mathrm{O}$ by XRD, XPS and FTIR. The element compositions of the borax crystal mainly include $\mathrm{Na}, \mathrm{B}$ and $\mathrm{O}$ according to the results of EDS and ICP-AES. Thus, this costeffective method can be easily applied to industrial scale-up preparation of borax for large-scale chemical and metallurgical applications.

\section{Acknowledgements}

This study was supported by the Ministry of Land and Resources of Public Welfare Scientific Research (No. 201411107-8), the National Natural Science Foundation of China (No. 51201022), the Hunan Provincial Innovation Foundation For Postgraduate (CX2016B399), and the Changsha University of Science and Technology Innovation Foundation For Postgraduate.

\section{Notes and references}

1 A. Biyikoglu and E. Yeksan, Int. J. Hydrogen Energy, 2008, 33, 7103-7109.

2 J. Nagamatsu, N. Nakagawa, T. Muranaka, Y. Zenitani and J. Akimitsu, Nature, 2001, 410, 63-64.

3 R. Boncukcuoğlu, M. M. Kocakkerim and M. Alkan, Water, Air, Soil Pollut., 1998, 104, 103-112.

4 S. Y. Qin, Y. F. Zhang and Y. Zhang, J. Cryst. Growth, 2016, 2016, 143-147.

5 I. M. Shyu and T. K. Liu, Combust. Flame, 1995, 100, 634-644. 6 A. Mergen, M. H. Demirhan and M. Bilen, Adv. Powder Technol., 2003, 14, 279-293.

7 H. H. K. Xu, J. B. Quinn, D. T. Smith, A. A. Giuseppetti and F. C. Eichmiller, Dent. Mater., 2003, 19, 359-367.

8 D. Yu, J. Wu, L. Zhou, D. Xie and S. Wu, Compos. Sci. Technol., 2000, 60, 499-508.

9 S. Y. Qin, B. W. Yin, Y. F. Zhang and Y. Zhang, Hydrometallurgy, 2015, 157, 333-339.

10 G. H. Li, B. J. Liang, M. J. Rao, Y. B. Zhang and T. Jiang, Miner. Eng., 2014, 56, 57-60.

11 V. Garnier, G. Fantozzi, D. Nguyen, J. Dubois and G. Thollet, J. Eur. Ceram. Soc., 2005, 25, 3485-3493.

12 J. Hu, W. D. Fei and C. K. Yao, J. Mater. Sci., 2001, 36, 48174821.

13 R. E. Kirk, H. F. Mark, J. J. Mcketta and A. Standen, Encyclopedia of chemical technology, Wiley, 1965.

14 R. Liu, X. Xue, T. Jiang, S. Zhang, P. Duan, H. Yang and D. Huang, Mater. Rev., 2006, 20, 1-4.

15 F. Ç. And and S. Kuşlu, Ind. Eng. Chem. Res., 2005, 44, 81648170 . 
16 İ. Y. Elbeyli, Hydrometallurgy, 2015, 158, 19-26.

17 Y. G. Ding, J. S. Wang, G. Wang, S. Ma and Q. G. Xue, J. Iron Steel Res. Int., 2012, 19, 09-13.

18 W. Xie, Z. Y. Tang and C. X. Zou, Mater. Rev., 2016, 30, 158162.

19 R. B. Kistler and C. Helvaci, Ind. Miner. Rocks, 1994, 171-186.

20 Roskill, The economics of boron, Roskill Information Services Ltd, London, 2002.

21 X. L. Fu, X. J. Yang and H. G. Fu, Shanghai Chem. Ind., 2016, 41, 16-19.

22 M. Özdemir and I. Kıpçak, Miner. Eng., 2010, 23, 685-690.

23 L. Bingling, Inorg. Chem. Ind., 2006, 34-36.

24 T. Jiang, L. Yin, L. Zhu and X. Xue, CIESC J., 2014, 65, 737743.

25 N. Acarkan, G. Bulut, O. Kangal and G. Önal, Miner. Eng., 2005, 18, 739-741.

26 E. C. Çilek and H. Üresin, J. Colloid Interface Sci., 2005, 290, 426-430.

27 A. K. Figen and S. Pişkin, Int. J. Hydrogen Energy, 2013, 38, 3702-3709.
28 L. T. Zhao, R. L. Li and C. Shi, Study on making borax form boron and magnesium mineral at $0.1 \mathrm{MPa}$, Shaanxi Chemical Industry, 2002.

29 Q. W. Li, F. Q. Liu and X. B. Deng, Iron, Steel, Vanadium, Titanium, 2012, 33, 7-11.

30 S. Bie, Z. J. Wang and Q. H. Li, Chin. J. Rare Met., 2010, 34, 291-297.

31 J. X. Liu, X. Y. Gao and L. X. Yang, Inorg. Chem. Ind., 1986, 5, 25-30.

32 X. J. Zheng, Paigeite processing, Chemical Industry Press, Beijing, 2009, pp. 36-40.

33 E. H. Park, S. U. Jeong, U. H. Jung, S. H. Kim, J. Lee, S. W. Nam, T. H. Lim, Y. J. Park and Y. H. Yu, Int. J. Hydrogen Energy, 2007, 32, 2982-2987.

34 H. A. Levy and G. C. Lisensky, Acta Crystallogr., Sect. B: Struct. Crystallogr. Cryst. Chem., 1978, 34, 3502-3510.

35 G. J. Gainsford, T. Kemmitt and C. Higham, Acta Crystallogr., 2008, 64, i24-i25. 